\title{
Can Cord Blood Serve as A Diagnostic Window?
}

\author{
Kharb $S^{*}$ and Nanda $S$ \\ Department of Biochemistry and Obstetrics and Gynecology, Pandit Bhagwat Dayal Sharma Post Graduate Institute of Medical Sciences, India
}

Submission: August 24, 2017; Published: October 13, 2017

*Corresponding author: Simmi Kharb, Department of Biochemistry and Obstetrics and Gynecology, Pandit Bhagwat Dayal Sharma Post Graduate Institute of Medical Sciences, India, Tel: 91-9812016036; Email: simmikh@gmail.com

Keywords: Cord blood; Maternal; Preeclampsia; Diagnostic; Markers

\section{Introduction}

Preeclampsia (PE) is a multisystem disorder and a leading cause of maternal and fetal mortality and morbidity. It is defined as $\mathrm{BP}>140 / 90$ with proteinuria $>300 \mathrm{mg}$ in $24 \mathrm{hr}$ urine on or after 20 week gestation.

\section{Pathophysiology}

Pathogenetic mechanisms implicated in preeclampsia include defective placentation, oxidative stress, auto antibodies to type-1 angiotensin II receptor, platelet and thrombin activation, intravascular inflammation, endothelial dysfunction and the presence of antiangiogenic state, among which an imbalance of angiogenesis [1,2]. Preeclampsia can manifest early or late. Early PE is due to impaired trophoblastic invasion of maternal spiral arteries. Late PE occurs as a result of metabolic disturbances along with trophoblastic invasion. PE is a 2 stage disease, namely, Stage1: maternal spiral artery undergo shallow invasion causing vascular resistance and decreased blood flow; Stage2: Vascular endothelium damage [2].

Other risks factors for PE include dysregulated G- protein coupled receptor signaling; increased vascular responsiveness to angiotensin II, lipid metabolism associated with oxidative stress; gene polymorphism and insulin resistance [1]. Placenta is the principal contributor to the pathogenesis of preeclampsia and delivery of placenta remains the only treatment for the clinical disease.

\section{Markers for Detection}

Various maternal factors such as inflammatory, metabolic and immunological disorders during pregnancy can affect the environment in which the fetus is developing and may produce immune, metabolic, hemodynamic, vascular and renal alterations. Studies of PE placental gene expressions have been shown to have a role of cytokine receptor gene, obesity related gene, apoptosis related gene in development of PE [35]. Proteomic or metabolomic approaches are under study [6], however, insufficient evidences are available regarding possible biomarkers and biologically active molecules which are diagnostic and predictive for early and later fetal and maternal complications.

\section{Can Cord Blood be of Great Diagnostic Value?}

Since umbilical cord blood (UCB) is in contact with all the fetal tissues and can reflect the state of fetus (both physiological and pathological if any) and UCB can be compared with maternal blood. During fetal development many regulatory substances are exchanged and released into UCB which could reflect physiological and pathological condition of fetus and pregnancy status. Neonatal proteome is yet to be compared with adult serum proteome and UCB has the advantage of ease to obtain with minimal risk to the donor.

\section{Peculiarities of UCB}

UCB is easily available bio fluid of diagnostic value. It can be obtained easily and poses small risks to donor. Also it is a potential source of biomarkers, stem cells. Such biomarkers required which are diagnostic and predictive for complications that result from an in - utero encounter such as infections. During fetal development many regulatory factors influences the fetus and metabolic products from fetus released into UCB. Changes in UCB proteins ( $\alpha$ - fetoprotein, adiponectin, leptin) use as diagnostic and therapeutic parameters to monitor fetal and neonatal disorders.

\section{Cord Blood Profile in Preeclampsia}

Abnormal level of maternal serum endothelial, soluble form like tyrosine kinase 1(SFlt-1), angiotensin II have been reported. Scanty data available regarding biochemical parameters. 
Changes in inflammatory response and endothelial dysfunctions are observed in umbilical cord blood from mothers with PE. It would be more realistic if a combination of clinical information and risk factors along with exploration of urine and blood biomarkers are carried out [2-5]. The children born of women with preeclampsia deserve a closer clinical follow-up later in life. Since there is increased awareness regarding fetal origins of adult disease, UCB screening has the potential for early diagnosis in neonates for future diseases [7].

\section{Conclusion}

Preeclampsia is a multisystem disorder, pathophysiology of which is still not clear. Preeclampsia is one of the leading causes of maternal and fetal morbidity and mortality. Epigenetic programming is altered during fetal life and postnatal period and after birth this scenario may change to metabolic syndrome complex or may contribute to future risk of hypertension, DM2, and cardiovascular disease. During gestation, complex physiological changes occur in maternal blood and fetal circulation. For studying next generation diagnostic biomarkers for maternal-fetal interface, it is essential to explore the biochemical changes in maternal serum during healthy gestation. Umbilical cord blood (UCB) is in contact with all the fetal tissues and can reflect both normal physiological as well as pathological states of the fetus. UCB can be compared with adult blood and the diagnostic potential of UCB still remains to be tapped. UCB will be a potential diagnostic medium in future in assessing infant health and can aid in detection and identification of candidate biomarkers for various disease pathways and can help in assessing the existing or future adverse effects. Future studies will further uncover the diagnostic value of the umbilical cord blood in human physiology and pathology.

\section{References}

1. Stepan H, Faber R, Dornhofer N, Huppertz B, Robitzki A, et al. (2006) New insights into the biology of preeclampsia. Biol Reprod 74(5): 772776.

2. Roberts JM, Cooper DW (2001) Pathogenesis and genetics of preeclampsia. Lancet 357(9249): 53-56.

3. Kharb S (2009) Serum markers in pre-eclampsia. Biomarkers 14(6): 395-400.

4. Enquobahrie DA, Meller M, Rice K, Psaty BM, Siscovick DS, et al. (2008) Differential placental gene expression in preeclampsia. Am J Obstet Gynecol 199 (5): 566-e1-11.

5. Kharb S, Batra A, Nanda S (2012) Cord blood atherogenic index in preeclampsia tracing fetal origins of adult disease. Res J Obstet Gynecol 5: 4-7.

6. Meng T, Chen H, Sun M, Wang H, Zhao Z, et al. (2012) Identification of differential gene expression profiles in placentas from preeclamptic pregnancies versus normal pregnancies by DNA microarrays. OMICS 16: 301-311.

7. Vuadens F, Benay C, Crettaz D, Gallot D, Sapin V, et al. (2003) Identification of biologic markers of the premature rupture of fetal membranes proteomic approach. Proteomics 3(8): 1521-1525.

\section{Your next submission with Juniper Publishers will reach you the below assets}

- Quality Editorial service

- Swift Peer Review

- Reprints availability

- E-prints Service

- Manuscript Podcast for convenient understanding

- Global attainment for your research

- Manuscript accessibility in different formats ( Pdf, E-pub, Full Text, Audio)

- Unceasing customer service

Track the below URL for one-step submission https://juniperpublishers.com/online-submission.php 